\title{
VIABILITY AND LEGALITY OF MUSLIMS OFFERING PRODUCTS OR SERVICES EXCLUSIVELY FOR MUSLIMS *
}

\author{
Nuraisyah Chua Abdullah** \\ Herwina Rosnan ${ }^{* * *}$ \\ Norzayana Yusof ****
}

\begin{abstract}
The debate on 'Muslim-Only Laundrette' in Johor, a state at southern Peninsular Malaysia has sparked outrageous responses from various levels of the society. Given the fact that there is scant literature to address this issue, by adopting the qualitative approach, this article aims to explore the issue, from a business perspective about where Muslim products and services stand in Malaysia and the legal aspects of offering goods and services exclusively from Muslims for Muslims. The right to segmentise customers based on religious grounds is critically analysed. This article discusses the governance of Muslim businesses, the issue of discrimination of goods and services in comparison with the position in the United Kingdom, United States of America and Australia. The possibility of mediation services in response to the national call for social harmony is also explored. This article concludes that detailed guidelines to differentiate discriminatory acts from adherence to religious duties should be given to service providers to avoid interreligious misunderstanding. The article further suggests that one of the possible marketing strategies to avoid discrimination claims could be to take a more moderate stand in marketing services such as 'clean, friendly services' and the like apart from marketing to the Muslim audience through targeted marketing
\end{abstract}

This is a revised version of a paper presented at the $21^{\text {st }}$ MACFEA National Seminar "Consumer Services and Protection: Ensuring Sustainability", 14-15 December 2017, International Islamic University of Malaysia, Malaysia.

** Associate Professor, Universiti Teknologi MARA, email: nuraisyahc@yahoo.com.

Lecturer at the Arshad Ayub Graduate Business School, Universiti Teknologi MARA.

**** Ph.D candidate at the Faculty of Business and Management, Universiti Teknologi MARA 
channels, such as Muslim media, local publications in Muslim majority countries, as well as targeted advertisement campaigns.

Keywords: Muslim-friendly goods and services; customer segmentation; community mediator; discrimination; interreligious conflicts

\title{
DAYA MAJU DAN KESAHIHAN PRODUK/PERKHIDMATAN DARI MUSLIMIN KHAS UNTUK MUSLIMIN
}

\begin{abstract}
ABSTRAK
Debat tentang 'Kedai Dobi Layan Diri Muslim Sahaja' di Johor, negeri di bahagian selatan Semenanjung Malaysia telah mendapat pelbagai respons daripada masyarakat. Oleh kerana kurangnya kajian yang mengenengahkan isu ini, makalah ini telah menggunakan kaedah kualitatif untuk menganalisa perspektif perniagaan tentang kedudukan barangan dan perkhidmatan Muslim di Malaysia. Makalah ini turut membincangkan aspek perundangan yang berkaitan dengan pelaksanaan perniagaan Muslim di Malaysia di samping hak untuk membuat segmentasi pelanggan mengikut aspek agama. Makalah ini menganalisa tadbir urus perniagaan Muslim dengan membuat perbandingan dengan negara-negara yang terpilih seperti United Kingdom, Amerika Syarikat, dan Australia. Pemakaian perkhidmatan 'timbang-tara' sebagai pilihan yang boleh digunakan dalam isu ini juga telah dikaji. Makalah ini membuat kesimpulan bahawa perincian garis panduan daripada pihak berkuasa adalah perlu untuk membolehkan peniaga Muslim mengenalpasti pendekatan perniagaan yang dianggap berdiskriminasi atau boleh menyebabkan salah faham antara penganut agama yang berbeza. Makalah ini juga mencadangkan strategi pemasaran yang lebih bersifat sederhana di mana slogan seperti 'perkhidmatan bersih, mesra' dan seumpamanya digunakan, selain daripada pemasaran kepada pelanggan beragama Islam melalui saluran pemasaran seperti media Muslim atau pemasaran kepada destinasi yang majoriti rakyatnya beragama Islam.
\end{abstract}

Kata kunci: Barangan dan perkhidmatan mesra muslim, segmentasi pelanggan, pengantara komuniti, diskriminasi, konflik antara agama 


\section{INTRODUCTION}

Confinement of goods and services to a certain group of people may trigger the issue of discrimination. Discrimination is defined as an exclusion of an individual or an entire group of people due to their participation in a particular social faction. ${ }^{1}$ The study on marketplace discrimination can be traced back to the 1930s, where privately owned accommodations and eateries in the United States of America (USA) is found to have refused to serve the non-American nation customers. ${ }^{2}$

Furthermore, it is also conceived that the two most marginalised groups of customers are the ethnic minority and the financially challenged. ${ }^{2}$ Thus, it is seen that the study of marketplace inequality has existed for over seven decades indicating the prolonged selective behaviour towards customers. Meanwhile, customer or marketplace discrimination is described as customers receiving differential treatments based on perceived group-level traits. Discrimination nowadays occurs in various services context such as car purchases, insurance and other financial services, medical care, restaurant, and attaining taxi services.

Tourism studies define religious products as sacred goods and activities that are offered and participated in fulfilling religious duties. ${ }^{3}$ Meanwhile, the consumption of religious products is termed as the extent of attachment to a particular religious culture. ${ }^{4}$ American use of religious products, for example, started back as early as in the $16^{\text {th }}$ Century which consists of a wide range of goods such as health foods, images of God,

1 Klinner, Nicole S., and Gianfranco Walsh. "Customer Perceptions of Discrimination in Service Deliveries: Construction and Validation of a Measurement Instrument." Journal of Business Research 66, no. 5 (2013/05/01/ 2013): 651-58.

${ }^{2}$ Mick, David Glen, Simone Pettigrew, Cornelia Connie Pechmann, and Julie L Ozanne. Transformative Consumer Research for Personal and Collective Well-Being. (New York: Routledge, 2012), 2.

${ }^{3}$ Burak, Kartal, Tepeci Mustafa, and Atlı Hakan. "Examining the Religious Tourism Potential of Manisa, Turkey with a Marketing Perspective." Tourism Review 70, no. 3 (2015): 214-31.

${ }^{4}$ Park, Jerry Z, and Joseph Baker. "What Would Jesus Buy: American Consumption of Religious and Spiritual Material Goods." Journal for the scientific study of religion 46, no. 4 (2007): 501-17. 
holy books and novels. ${ }^{4}$ As non-print media technologies such as radio and television were developed in the $20^{\text {th }}$ Century, religious television and radio went to a broader scale, such as sermons and television series. In Malaysia, Johan Fischer's book Proper Islamic Consumption: Shopping among the Malays in Modern Malaysia posited that the consumption of religious products in Malaysia was constituted from the country's nationalist vision that combined consumption and Islamic practice. ${ }^{5}$ The recent debate on 'Muslim-Only Laundrette' triggered the discussion on the right of the service provider to segmentise its customers based on a religious basis. Using the qualitative approach, this paper aims to explore the business perspective of Muslim products and services and the legality of segmenting customers based on religious grounds. Finally, the article suggests the way forward to address this issue.

\section{GOVERNANCE OF MUSLIM BUSINESSES IN MALAYSIA}

The Ninth Schedule of the Malaysian Federal Constitution provides for the general distribution of legislative powers between the federal and state governments: List I (Federal List) List 11 (State List) and List III (Concurrent List). In addition, the Ninth Schedule includes list 2A (Supplement to State List for Sabah and Sarawak) and List 3A (Supplement to Concurrent List for the States of Sabah and Sarawak). Although the Federal Constitution guarantees the separation of powers between the federal and state according to the Lists, it has however extended the jurisdiction of the federal government by allocating power to make laws in respect of all matters listed in the Federal List (for example, Trade, commerce and industry, including production, supply and distribution of goods, price control and food control, adulteration of foodstuffs and other goods) and the Concurrent List. The federal government can introduce laws on state matters at the request of the state legislative assembly or for purposes of ensuring and promoting uniformity between the laws of two or more states. The distribution of legislative powers is centralised in the federal government whereas the states are left with less critical responsibilities (Article 73(b) of the Federal Constitution). This central bias in the distribution of the

${ }^{5}$ Daniels, Timothy P. "Johan Fischer, Proper Islamic Consumption: Shopping among the Malays in Modern Malaysia." Contemporary Islam 6, no. 1 (2012): 85-88. 
legislative and executive powers is evident in Articles 73-81 of Part VI of the Federal Constitution whereby the federal government is permitted to make laws for the whole or any part of the country while the states have the powers to make laws only within their jurisdictions.

Local authorities are established under the Local Government Act 1976 (Act 171) and the respective state ordinances and by-laws. Each local authority is a separate legal entity from the federal or state government or other local authorities. The local authorities are responsible for the domestic affairs based on the powers set by the federal or state government. They carry out their functions in accordance with the law provided. The area of administration is based on the population size and can be within the city, municipal or district. As such the local authority can be the City Hall/Council, Municipal Council or the District Council. Generally, the local authorities are responsible for numerous services related to housing, waste management, taxation, land assessment, the cleanliness of the environment, public amenities/facilities, social obligation and development of their local jurisdictions. Under the Local Government Act 1976, section 107, a local authority not only has the right to grant any licence or permit of any trade in its locality, it may also prescribe the fees for such licence or permit and the charges for the inspection or supervision of any trade, occupation or premises in respect of which the licence is granted.

When Malaya chose the UK model of constitutional monarchy system after independence in 1957, it was an undisputable social contract between the people and the rulers that the people agreed to accept the rulers as their constitutional monarchs who would exercise their powers as provided by the constitution. Similarly, the rulers also agreed with these conditions. The jurisdiction of the rulers over religious and customary matters that was in existence since the British rule was reinforced during the formation of the Federal Constitution. However, the constitutions of the various states, as well as the Eighth Schedule of the Federal Constitution, confer on Their Majesties discretionary powers in some fields, and in the context of this discussion, functions as the Head of the Religion of Islam for the respective states (Article 3(2) of the Federal Constitution). However, the role of the rulers in many occasions illustrates that they not only function in religious matters but beyond that, which includes as the check-and-balance mechanism in the country, as an advisor against wrongdoings and as a court of last resort against the arrogance of power. For example, the Selangor Ruler rose to the occasion in 2006 to bring a halt to a Klang strongman's controversial properties. 
The assets were built without council approval along with failure to pay property assessments. Hence, the Ruler reprimanded him to resign as a counsellor, pay his assessments, submit approval for buildings, and mind his manners or he would risk having his Datukship revoked. ${ }^{6}$

\section{DEBATABLE 'MUSLIM-ONLY LAUNDRETTE'}

Muslims represent an estimated $23 \%$ of the global population or about 1.8 billion consumers with an average growth rate of $3 \%$ per annum ${ }^{7}$. The global Muslim population is expected to grow by about $35 \%$ over the next 20 years, rising from 1.6 billion in 2010 to 2.2 billion by 2030 , or 26.4 percent of the world's total projected population of 8.3 billion. By 2050 , the Muslim population could grow to 2.6 billion and represent nearly $30 \%$ of the projected global population. ${ }^{8}$

Companies are coming to understand the great opportunity that the Muslim consumer represents. However, addressing this market is not as straightforward as dealing with other billion population consumer markets such as India and China. For a start, the Muslim community is not a single homogeneous group. Muslims live in every country in the world, represent every race and come from every social and economic stratum. Although they share the common thread of their beliefs, they have their own cultural, regional or local nuances, preferences and practices.

On 24 September 2017, the Muslim service industry was triggered with the debate on the notice of 'Muslim-Only' signboard at a Johor (a state at the south of Peninsular Malaysia) business premise whereby the premise denied its service to the non-Muslims. Although it sparked outrages comments on social media-commenting that such acts are racist and discriminating against a large number of population in Malaysia, some others (for example, the advisor for Johor Islamic Affairs Department) stood by the laundrette's owner's justification - to ensure the purity of Muslim clothes, in avoidance of contaminated clothes from

${ }^{6}$ Wong Chun Wai, "It's Serious When the Selangor Sultan Has to Step In," The Star, October 30, 2006, accessed on November 5, 2017.

${ }^{7}$ Dar, Humayon, Nursofiza Azmi, Rizwan Rahman, and Rizwan Malik. Global Islamic Finance Report: Gifr 2013. (Edbiz Consulting, 2013), 140.

${ }^{8}$ Majlis, Fleishman-Hillard. "The Next Billion: The Market Opportunity of the Muslim World. " Majlis White Paper (2011): 2. 
faecal matters for example dogs, which were brought to the business premise by non-Muslim customers. ${ }^{9}$ Ironically even though the sign at the business premise was changed to 'Muslim-friendly', the Ruler of Johor, Sultan Ibrahim Ibn Almarhum Sultan Iskandar, demanded the business to stop what is perceived as a discriminatory act or else they will face shut down. ${ }^{10}$ As the Head of the religion of Islam, His Majesty's stand was that businesses in Johor should not practice discrimination based on the issue of religions and races as such practice may mislead to portray the extremist nature of Islam.

There is contention that the 'Muslim-Only Laundrette' is a threat to the Malaysian multi-racial and harmonious religious society to the extent that there is proposal by various organisations such as the Malaysian National Unity Consultative Council (NUCC) and Asli Centre for Public Policy Studies to revisit the National Harmony and Reconciliation Bill. ${ }^{11}$

The Bill was proposed by NUCC in 2013, aimed at strengthening National Unity, curtailed racial and religious disputes, but was disregarded a few years back. It is contended that the Bill negates any kind of activities that could jeopardise the national peace and it was suggested that it might be the legal mechanism to prevent such nonharmonious activity of the 'Muslim-Only Laundrette'.

Some proposed that the local authority should have taken preventive measures to avoid the non-harmonious business before the comments were made by the Ruler of Johor. Among the prominent licensing authorities that supervise businesses in Malaysia is the Ministry of Domestic Trade, Co-operatives and Consumerism (MDTCC). The Ministry offers licensing procedures only on certain products such as petroleum, scheduled control goods license, import and export of sugar and flour. While application guidelines are presented for each of the types of license, a general guideline on the management of the business is not provided. Although the Ministry offers retail training programmes for

9 "I Am Fulfilling Religious Obligation, Says Muslim-Only Laundry Service Operator," The Sun Daily, September 26, 2017, accessed on October 10, 2017).

10 "Royal Dressing Down for Muslim-Only Launderette," The Sun Daily, September 27, 2017, accessed on October 10, 2017.

${ }^{11}$ Augustin, Robin, "Time to Look Again at Unity Council's Ideas?" FMT News, September 28, 2017, accessed on October 10, 2017; "Revive National Harmony Bill," The Star, September 28, 2017, accessed on October 10, 2017. 
small and medium (SME) entrepreneurs in pushing their products into foreign hypermarkets in Malaysia, equivalent attention is not given in the context of the equality of commercial services offered to the consumers. ${ }^{12}$

The local authority has the jurisdiction to create laws and rules (in the form of by-laws) and to grant licenses and permits for any trade in its area of jurisdiction and as such, the local council is responsible at granting a license to premise and business advertisement board to business operators. The Kuala Lumpur City Hall, for example, provides the guidelines and terms and condition in the e-Lesen website. It explains the requirement of displaying premise license at the premise. Accordingly, the site listed several statutes that businesses need to adhere to including the Laundrette By-Laws (Federal Territory of Kuala Lumpur 1985) but without its details. ${ }^{13}$

The Licensing of Trades, Businesses and Industries (Federal Territory of Kuala Lumpur) By-Laws 2016 outlined the criteria for running specific wooden store, laundry and beauty and healthcare centre, as well as general businesses. Generally, businesses are required to adhere to the cleanliness, lighting, ventilation and safety requirements of premises. Moreover, the by-laws also discuss employment requirements and that businesses must be free from activities that could cause dispute to the community. Specifically in Part IV (sections 14-17) of the By-laws - for laundry services, attention is given to cleanliness and ways of handling the clothes.

The Muar Municipal Council also approves licenses to billboards, signage and banners. Nevertheless, it only provides a general guideline on how the design should be, and that if the owner does not include its business activities in the signage, it should be written separately but displayed in the premise. ${ }^{14}$ Hence, specific guidelines on whether service providers can be selective of their customers - are not discussed in the local authorities' guidelines and as such, any argument (if any) to the effect that there is a violation of any local authorities guideline would not be a valid argument in the 'Muslim-Only Laundrette' debate. However, this situation does not negate the local authority's rights to supervise and

${ }^{12}$ Ministry of Domestic Trade Co-operatives and Consumerism. "Licensing Management."

${ }^{13}$ Licensing and Development Hawker. "Premise." (2011).

14 Muar Municipal Council. "Application Form for Advertising License/ Banner." Accessed November $10^{\text {th }}, 2017$ 
monitor businesses which may cause discomfort to the local community as the power of the local authority is wide as discussed earlier.

\section{EVALUATION OF MUSLIM PRODUCTS AND SERVICES IN MALAYSIA}

The Malaysian National Consumer Policy, launched on 26 July, 2002 does not explicitly state the rights of consumers but on the other hand states the responsibilities essential to all consumers, i.e. awareness to criticise, involvement, action and social responsibility. The National Consumer Advisory Council, a body that serves to advise the Minister in the Ministry of Domestic Trade, Cooperatives and Consumerism, has outlined eight rights the consumers must know, which includes the consumers' rights to choose. The right to choose evolved and originated from the right to make a choice, i.e. one of the eight rights of a consumer as proclaimed by the former US President John F. Kennedy on 15 March 1962. The consumer's right to choose means the consumer should be able to select from a range of products and services, offered at competitive prices with an assurance of satisfactory quality.

There is an absence of the definition of 'right to choose' in the Malaysian Consumer Protection Act, 1999. However, the definition is provided under the Indian Consumer Protection Act 1986 where it is defined as 'the right to be assured, wherever possible, to have access to a variety of goods and services at competitive prices'. The right to choice appears to deviate from the concept of 'exploitation theory' ${ }^{15}$ which was prevalent during the 1960s and 1970s, as when there is a variety of goods and services available to the consumers for the consumers to choose, consumers have more options to purchase and contract on the terms which vary due to more options in business marketing strategies. Variation of nature of services increases competition between companies, signifying positive response towards consumer rights. The right to choose is closely connected with the information which is revealed to consumers while buying the product, enabling consumers to exercise his right to choose. Hence, in this context, information asymmetries occur when one party to a transaction knows more about the quality of the product or services offered than the other. In the context of Muslim products, when

${ }^{15}$ Under this theory, the consumers are regarded as the weak party, who is at the mercy of business operators. 
the product is explicitly mentioned to cater for Muslims, this allows the Muslims to be able to increase his expectation that the product conforms with the Islamic requirements of a halal product. The appendage of "Halal" or 'Muslim-friendly' to a product is not just a guarantee that the product is permitted for Muslims, but it has also become a global symbol for quality assurance and lifestyle choice.

The halal market can be divided into two large blocks, i.e. Muslims (the majority) and non-Muslims (a growing minority). Non-Muslim halal consumers are those regular or sporadic consumers of halal products, primarily in the food sector and their tendencies to choose other halal products will expand over time. The halal market is non-exclusive to Muslims and has gained increasing acceptance among non-Muslim consumers who associate halal with ethical consumerism. As such, the values promoted by halal - social responsibility, stewardship of the earth, economic and social justice, animal welfare and ethical investment - have gathered interest beyond its religious compliance. The popularity of, and demand for, halal certified products among non-Muslim consumers have been on the rise as more consumers are looking for high quality, safe and ethical products.

The halal industry has now expanded beyond the food sector to include pharmaceuticals, cosmetics, health products, toiletries and medical devices as well as service sector components such as logistics, marketing, print and electronic media, packaging, branding, and financing. Muslim-friendly goods and services in Malaysia are available in various industries including hotels, airlines and hospital services. These products are driven by the Islamic tourism industry that also focuses on Halal food and accessibility to prayer facilities. The Islamic tourism industry has developed various infrastructure to encourage the inbound of Muslim travellers into Malaysia, and the efforts have been fruitful as reported by Standing Committee for Economic and Commercial Cooperation of the Organization of Islamic Cooperation (COMCEC). Accordingly, Malaysia ranked $5^{\text {th }}$ after Saudi Arabia, Turkey, United Arab Emirates (UAE) and Bahrain in the 2014 Muslim visitor arrivals that had brought in USD 4,290 million into the economy. ${ }^{16}$ In 2014, Malaysia received 5.27 million visitors, and the

${ }^{16}$ COMCEM Coordination Office. "Muslim Friendly Tourism: Understanding the Demand and Supply Sides in the Oic Member Countries." Ankara: 
figure is expected to grow to 6.59 million in 2020 . There are six values that Muslim tourists uphold in their destination countries. Those are access to products with quality value, value for money, the enjoyment that is delivered with, the message that the products offer to others, and tangible and intangible attributes of Shari'ah-compliant tourism products. ${ }^{17}$ Therefore, it is proven that providing Muslim-friendly goods and services encourages economic development because it caters for a huge pool of customers from both the locals and tourists. Moreover, the tagline that is used by the Islamic tourism industry to foster the growth is "Muslim Friendly Malaysia", thus, the Muslim-friendly Laundrette is in line with the Islamic tourism industry tagline for its businesses, whose aim is to attract and facilitate the Muslim travellers.

Similar to the Muslim-friendly Laundrette, the Muslim-friendly hospitality services is defined as products or services in the travel and tourism industries guided by Shari'ah requirements that cater to or provide for facilities that aid Muslim travellers. ${ }^{18}$ Thus, it suffices to say that Muslim services on other facilities such as swimming pools or salon for female Muslims are defined as services that adhere to the Shari'ah requirements that provide for local and international female Muslims. Therefore, service providers are reciprocating to the demand by executing several strategies. Service Quality (SERVQUAL) considers consumers expected service and perceived service. Moreover, businesses also place emphasis on the swimming pool atmosphere such as aesthetical values and the design that separates men and women. ${ }^{19}$ It is also believed that the same strategies apply to other services such as salon too because of the similar nature of exposing the customers' hairs and other body parts that are considered as aurah for female Muslims.

Standing Committee for Economic and Commercial Cooperation of the Organization of Islamic Cooperation (COMCEC), 2016.

${ }^{17}$ Eid, Riyad, and Hatem El-Gohary. "The Role of Islamic Religiosity on the Relationship between Perceived Value and Tourist Satisfaction." Tourism Management 46, no. Supplement C (2015/02/01/ 2015): 477-88.

${ }^{18}$ Islamic Tourism Centre. "Malaysia Islamic Tourism - Facts and Figures in Brief 2014/2015." Ministry of Tourism and Culture Malaysia, 2015.

${ }^{19}$ Hardianto, Anneke Ratnasari, and Ririn Tri Ratnasari. "Factors Influencing Consumers on Choosing Al-Hikmah Sport Center Muslimah Swimming Pool in Surabaya." Jurnal Ekonomi Syariah Teori \& Terapan 2, no. 2 (2015): 91107. 
However, the Muslim-friendly products and services in halal branding are facing numerous challenges. In a recent international halal tourism congress, it is argued that the costs of attaining the halal certificate from the authority where in Malaysia, JAKIM, could hinder businesses from expanding their Muslim-friendly products. The industry is also challenged by the potential separation of various tribes and religions when the term "Muslim-friendly" is applied. ${ }^{20}$

In Malaysia, the MS2610:2015 Muslim-friendly hospitality services was published as the first standards on Islamic tourism that provides guidelines on accommodations, tour packages and tourist guides. ${ }^{19}$ Nevertheless, the adoption of this standard is voluntary and not subjected to any certification requirement thus creating variations as to what makes a product Muslim-friendly. Potentially, it could lead to misuse of the term only to attract Muslim customers. Moreover, the extent of Muslims practising Islamic teachings is also voiced out as one of the hurdles in this industry. While some practise veiling and consider their clothes cleanliness from faecal matters seriously, others may not. This reflects a challenge for Muslim-only service providers to view the market as homogeneous and to design their services to cater the differing level of conservatism among customers. ${ }^{21}$ Despite Muslim tourists' increasing tendencies to Shari'ah compliant products, the extent that consumers would comply to such behaviours would depend on their religiosity and culture level. ${ }^{22}$

Nevertheless, it is also important to understand that the prospect for Muslim-friendly products in Malaysia is expected to be increasing. The 2020 inbound Muslim visitors are anticipated to reach 6.59 million people, contributing USD \$5,228 million to the economy (COMCEM Coordination Office 2016). This is driven by the strengths of Malaysia's Muslim-friendly products such as prayer facilities at tourist spots and

20 Wilson, Jonathan A.J. "Nation Branding Halal: Challenges and Opportunities." (paper presented at the International Halal Tourism Congress, Alanya, Turkey, April 7-9, 2017)

21 Bogan, Ezhan, and Mehmet Sarisik. "Halal Tourism: Conceptual and Practical Challenges." (paper presented at the International Halal Tourism Congress, Alanya, Turkey, April 7-9, 2017).

${ }^{22}$ Stark \& Fine 2000, cited in Park, Jerry Z, and Joseph Baker. "What Would Jesus Buy: American Consumption of Religious and Spiritual Material Goods." Journal for the scientific study of religion 46, no. 4 (2007): 501-17. 
public premises, a wide variety of halal food and availability of Muslimfriendly healthcare facilities. Specifically for a Muslimah-only swimming pool, there are several factors that drive consumers in taking up the service. Those include, but not limited to, faith, perception, lifestyle, demography and personality, culture and upbringing. ${ }^{20}$

Furthermore, it is also reported that "recreational facilities with privacy" is among the faith-based needs of Muslim travellers which they look for in the destination countries. Such facilities include hotels whereby certain service provider such as the PNB Darby Park that requires their guests to declare that the person who is sharing the room is their mahram. Meanwhile, the Grand Bluewave Hotel Shah Alam describes privacy as facilities that separate the males from the females in their $17^{\text {th }}$ floor of the hotel. Separation is also available in spa, gymnasium and swimming pool.

Thus, it is seen that Muslim tourists place emphasis on concentrated services based on gender as part of their beliefs in complying with the Shari'ah compliant concept of consumer goods and services. Although there is no research mentioning that Muslim travellers prefer coming to Malaysia due to the concentrated services exclusively for Muslims, separation and privacy from this group of people is worth looking at. This brings the discussion back to the laundrette services, where certain groups of consumers who hold a stronger religiosity on Islamic practices might be concerned about their clothes' cleanliness from faecal matters from dogs that could be found on the non-Muslims' clothes. They may posit that dogs' fur could be attached to the non-Muslims clothes and could affect the purity of the machines thus affecting theirs too. Hence, service providers need to look into the heterogeneity of Muslim customers' religiosity, it is essential to consider providing services to a concentrated group of customers.

\section{CAN PROVIDING SUCH SERVICES ONLY TO MUSLIMS AMOUNT TO DISCRIMINATION?}

There is currently absence of any specific laws in Malaysia pertaining to discrimination of commercial services in Malaysia. Unlike Malaysia, in the U.K., it is unlawful for anyone who is concerned with the provisions of goods, facilities or services to the public or a section of the public to discriminate in relation to their provisions under the Sex Discrimination Act 1975 and 1986 and the Race Relations Act 1976. This could take the form of refusing or deliberately omitting to provide them, or refuse or 
deliberately omitting to provide goods, facilities or services of like quality or to that normally provided; or refusing or deliberately omitting to provide them on like terms or in like manner as normal. ${ }^{23}$ However, it should be noted that these two statutes only apply to service providers who provide for the public or a section of the public, hence, private clubs where memberships are given to selected members are excluded from these two statutes. The statutes also exempt small premises from the requirements relating to the provision of accommodation. It is interesting to note that the Sex Discrimination Act 1975 makes it clear that service providers do not have to provide a service for men and women when these are commonly provided in a different manner and it is possible to restrict facilities and services to one gender under the statute in certain circumstances (for example, to avoid serious embarrassment) under section 35 of the statute, where single-sex swimming arrangements in inns should not contravene the statute. ${ }^{24}$ The UK Equality Act 2010 replaced various anti-discrimination laws (for example the Sex Discrimination Acts and the Race Relations Act 1976) with a single Act. It simplified the legislation, removed inconsistencies and made it easier for people to understand and comply with it. It also strengthened the law in important ways to help tackle discrimination and inequality. It came into force in October 2010. Under this statute, service-providers are defined as persons concerned with the provision of services, goods or facilities to the public or a section of the public, regardless of whether or not a payment is provided and regardless of whether or not the relevant persons are exercising a public function. A protected characteristic including religion or belief can be the reason for the different treatment and it is because of that characteristic that the less favourable treatment occurs in the rendering services or goods.

In the absence of specific anti-religious-discriminatory provisions in many jurisdictions including Malaysia, it would appear that although a discriminatory level of service may cause customers frustrations, targeting specific consumer segmentation is a lawful strategic approach for service providers as it is meant to facilitate the needs of the segmented consumers. It is conceived that there are six values that Muslim tourists uphold in their consumptions in destination countries. Those are access to products with quality value, value for money, the

${ }^{23}$ Abdullah, Nuraisyah Chua. Rights and Liabilities of Holidaymakers and Holiday Provider (Petaling Jaya: International Law Book Services, 2009). 
enjoyment that is delivered with, the message that the products deliver to others, and tangible and intangible attributes of Shari'ah-compliant tourism products. ${ }^{24}$

The United States of America's Civil Rights Act of 1964 stated that privately owned places of public accommodation are prohibited from discriminating by race, colour, religion or national origin. Such businesses includes hotels, restaurants, theatres, banks, stores and health clubs. ${ }^{25}$ In Australia, business owners are allowed to stop someone from entering their businesses or refuse to serve someone so long that they do not breach anti-discrimination laws. By this, it means that the Australian Human Rights Commission is upheld whereby discrimination occurs when business owners refuse their service to customers based on age, sexual orientation, gender identity or intersex status, race and disability. ${ }^{26}$ Nevertheless, businesses have the right to refuse certain customers based on, but not limited to, dress code, disruptive behaviour, legal requirements, and safety reasons.

In detail, a dress code would apply to inappropriate attire, and it does not reflect current community standards for men and women. Meanwhile, disruptive behaviour is pertinent to refusing service to a person or group of customers who had caused trouble before. Due to the negative experience, the owners are allowed to ban certain customers from taking their service. On the other hand, legal requirements would mean that service providers are allowed to refuse their service, such as alcoholic drinks to a particular group of people because the law prohibits such action. Furthermore, safety reasons are termed as refusing to serve to customers because it could potentially cause harm to both or either one party.

${ }^{24}$ Errid Hadisyah Putra, Sri Rahayu Hijrah Hati, Sri Daryanti, "Understanding Muslim Customer Satisfaction with Halal Destinations: The Effects of Traditional and Islamic Values," The European Proceedings of Social and Behavioural Sciences, BE-ci 2016: 3rd International Conference on Business and Economics, 21 - 23 September, 2016.

${ }^{25}$ Haskins, Jane. "The Right to Refuse Service: Can a Business Refuse Service to Someone?" https://www.legalzoom.com/articles/the-right-to-refuseservice-can-a-business-refuse-service-to-someone-because-of-appearance, accessed November, 3, 2017.

${ }^{26}$ business.gov.au. "Refusing Service," https://www.business.gov.au/about, accessed November 3, 2017. 
Hence, it is seen that service providers have the right to entertain only a specific group of people, such as in the case of the laundrette, to meet the Muslim customers' values as discussed above. Since the heterogeneity of the global Muslim practices is acknowledged, it is the service providers' rights to choose their consumer segmentation to those who prefers not to share their privately-owned facilities. This is so because there are Muslims who are conscious about their cleanliness that they would want to minimise the possibility of jeopardising the purity of their clothes from matters such as dogs fur should be allowed to do so without being labelled as discriminating against non-Muslim consumers.

\section{COMMUNITY MEDIATOR AS AN INTERMEDIARY}

Literature in the 90's elaborated on the role of religion in conflict. Such includes the formulation of religious movements and grievance-formation by religious and ethnic minorities. ${ }^{27}$ Nevertheless, religious values are as equally crucial as cultural values in transforming feud to an agreement. ${ }^{27}$ In fact, it is argued that culture is a wide concept because it includes grouping that derives from profession, class, religion or region and not a mere tribe, ethnicity and national. There is no exact theory found on interreligious conflict resolution, but the integration of spirituality in conflict resolutions are abundant. For instance, Mahatma Gandhi's Tolstoy Farm, in particular, the religious fasting and dietary intake, was a means to promote mutual respect and tolerance between religions. ${ }^{28}$ Religion is deemed to be suitable to the conflict resolution theory based on several values that they possess. Those are empathy, sanctity in life, discipline and compassion.

Therefore, a training model on interreligious peace-building was introduced to facilitate the change from narrow and prejudiced attitudes and perspectives to a more tolerant one. ${ }^{27}$ Such effort is called for, along with inter-religion dialogues as means to curtail interreligious conflicts. ${ }^{29}$

27 Abu-Nimer, Mohammed. "Conflict Resolution, Culture, and Religion: Toward a Training Model of Interreligious Peacebuilding." Journal of Peace Research 38, no. 6 (2001): 685-704.

${ }^{28}$ Gopin, Marc. "Religion, Violence, and Conflict Resolution." Peace \& Change 22, no. 1 (1997): 1-31.

29 Isola, Olusola O. "Inter-Faith Conflict Mediation Mechanisms and Peacebuilding in Nigeria." In First Annual International Conference on 
Hence, expanding the understanding of the non-believers or outsiders would be a considerable challenge. ${ }^{28}$ This could lead to the adoption of community mediation as an alternative to interreligious and racial disputes. Accordingly, Community Mediation Centres are applied in certain countries including Malaysia. Hence, it is essential to look into its potential to solve racial and interreligious disputes in the country.

Community mediation derives from traditions from around the world, but mediation is although claimed to be a "uniquely American experience", has in fact spread to many parts of the world ${ }^{30}$ The National Association for Community Mediation (NAFCM) in the USA defines community mediation centres as having nine characteristics, four of them is fundamental to acquiring membership with NAFCM, i.e. being nonprofit/public agency, utilising volunteer mediators, providing direct access to public and providing services regardless of ability to pay.

The sector of community mediation is hard to categorise, but most of the centres are private non-profit agencies, and most are not funded with any federal money. There are specific characteristics of the majority of community mediation centres: most mediators practice highly value independence and neutrality; many centres serve as contractors of other agencies thus receiving referrals; usually there are a large number of cases referred by the courts; participants have a high level of selfdetermination throughout the process; community outreach is crucial; funding varies across the country, and most centres use a facilitative model of mediation. A plethora of issues is handled through mediation including neighbourhood, victim/offender restorative justice, small claims, landlord-tenant, custody and visitation/family matters, schoolrelated matters, interpersonal differences, and large group consensus building and decision making. Participation in community mediation is fundamentally voluntary - both for participants and mediators. In some countries like the U.S., mediators represent the diversity of the community, and they need to attend a $30-50$ hour basic training as well as other required continuing education activities.

Ethnic and Religious Conflict Resolution and Peacebuilding. New York: International Center for Ethno-Religious Mediation, 2014.

${ }^{30}$ Hedeen 2004, p. 101; Hedeen, Timothy. "The Evolution and Evaluation of Community Mediation: Limited Research Suggests Unlimited Progress." Conflict Resolution Quarterly 22, no. 1-2 (2004): 101-33. 
In Malaysia, the National Unity Consultative Council (NUCC) was established on $11^{\text {th }}$ September 2013, to settle any intercultural or interreligious dispute in Malaysia. Following the $13^{\text {th }}$ General Election as indicators that racial polarisation were apparent, ${ }^{31}$ the government believed that an independent mechanism was needed to reduce racial division and develop a united Malaysia country. The objectives of NUCC establishment are to find solutions for racial or religious issues and bridge the unity gap. The council is the following result of previous bodies that played similar roles. First in line was The National Unity Council (19691971), which was established based on the Ordinance (Kuasa-kuasa Perlu) Dharurat, 1969 and Peraturan-Peraturan Perlu (Majlis Perpaduan Negara), 1971 in response to the $13^{\text {th }}$ May 1969 racial riot.

However, the council was disbanded as the parliamentary democratic government was recovered. Then, the National Unity Advisory Council was established as chaired by the Prime Minister. With 51 multiracial members, they maintained the roles of the National Unity Council. Both bodies were then merged and became the Ministry of National Unity on

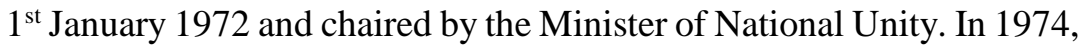
the agency was rebranded as National Unity Advisory whereby the members were reduced to 16 and headed by the Pengerusi Kerja Lembaga Perpaduan Negara. As changes in the name and chairperson occurred in the subsequent years, the NUCC was then established.

The NUCC provides a variety of services including Community Mediator which aims at reducing racial clashes thus enhancing social harmony. Its role is to provide mediation services voluntarily to the persons in need, finding solutions to settle their conflicts and providing training and experience sharing to increase mediation practices. However, the Mediation Act 2012 posits that planned, attempted or ongoing criminal activities are excluded from the community mediation process.

In the recent 'Muslim-Only Laundrette' issue, meetings between mediators and disputants (in the case of the 'Muslim-Only Laundrette' issue - the operator), called a caucus, could encourage disputant flexibility and problem solving. ${ }^{32}$ Nevertheless, meeting the outcome is

31 Department of National Unity and Integration. "National Unity and Consultative Council.," accessed November 2, 2017.

${ }^{32}$ Welton, Gary L, Dean G Pruitt, Neil B McGillicuddy, Carol A Ippolito, and Jo M Zubek, "Antecedents and Characteristics of Caucusing in Community 
largely depending on the mediators' background, gender, legal experience and that them being facilitators to the disputants. ${ }^{33}$ Community Mediators are tasked with consulting the plaintiff and defendant, on how to improve their relationships which may be an option to find out the response of the community pertaining to the commercial religious dispute in the locality. Since they are also responsible at directing disputants towards executing the possible resolution, it is proposed that solution-proposing questions should be asked, instead of merely providing the answers to solve their disagreements as this may lead to a better understanding between the service provider and the community in the event of dispute pertaining to commercial religious discriminatory services. The roles of mediators are important as they can help commercial providers to solve their societal problems with the community when they have already failed to resolve it themselves, thus reducing religious tensions amongst the society.

\section{CONCLUSION}

It is seen that clear guidelines for service providers to conduct their businesses in Malaysia is still grey in certain areas especially when the businesses attract religious and/or racial sensitivity. One of the possible marketing strategies to avoid discriminatory claims as in the 'MuslimOnly Laundrette' case in Johor, could be that business operators should take a more moderate stand in marketing services such as 'clean friendly services' and the like, following the example of hotel/destination, for example, Al Jawhara, a Dubai-based hotel group, which does not use the terms "Muslim" or "Halal". In their advertisement, Jawhara promotes its "unique family-oriented hospitality", despite the fact that the hotel clearly caters for Muslim needs. Another hotel group that successfully accommodates Muslim needs while being inclusive and not branding itself as a Halal hotel is Shaza Hotels. The luxury hotel operator focuses on authentic Arabian hospitality while being value-driven, and therefore appeals to both Muslims and non-Muslims alike. Another way to avoid

Mediation." International Journal of Conflict Management 3, no. 4 (1992): 303-17.

${ }^{33}$ Alberts, Jess K, Brian L Heisterkamp, and Robert M McPhee, "Disputant Perceptions of and Satisfaction with a Community Mediation Program," International Journal of Conflict Management 16, no. 3 (2005): 218-44. 
the dilemma of marketing to Muslims while non-alienating others, is to market to the Muslim audience through targeted marketing channels, such as Muslim media, local publications in Muslim majority countries, as well as targeted advertisement campaigns.

Muslim products or services meant for specific Muslim consumers appear to be a lawful strategic approach for service providers in countries which do not have specific discriminatory laws including Malaysia, as such practices are not in contravention with any existing laws when it is meant to facilitate the special needs of the Muslim consumers. With the recent 'Muslim-Only Laundromat' debate, this article calls for policymakers to revisit their guidelines on the issue of segmentation of services by service providers if this aspect is seen to be one that could affect the social harmony. Aside from that reliance on community mediation could play an important role in resolving sensitive cultural or religious issues within the community so as to enable both sides to understand the reasons for certain sensitivities. 